Utah State University

DigitalCommons@USU

1979

\title{
The identification of tobacco necrosis virus in deteriorating clones of aspen
}

\author{
C.R. Hibben \\ J. Reese \\ R.F. Bozarth
}

Follow this and additional works at: https://digitalcommons.usu.edu/aspen_bib

Part of the Forest Sciences Commons

\section{Recommended Citation}

Hibben, C. R.; Bozarth, R. F.; Reese, J. 1979. The identification of tobacco necrosis virus in deteriorating clones of aspen. Forest Science 25 (4): 557-567.

This Article is brought to you for free and open access by the Aspen Research at DigitalCommons@USU. It has been accepted for inclusion in Aspen Bibliography by an authorized administrator of DigitalCommons@USU. For more information, please contact

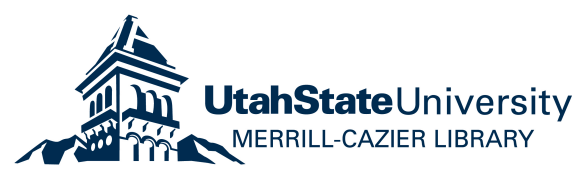




\title{
Identification of Tobacco Necrosis Virus in Deteriorating Clones of Aspen
}

\author{
Craig R. HibBen \\ ROBERT F. BOZARTH \\ JUdiTH REESE
}

\begin{abstract}
Aspen (Populus tremuloides) is deteriorating in some sites in the middle Rocky Mountain region. Several causal factors have been implicated, but the exact etiology of aspen deterioration remains unknown. Foliar symptoms indicative of virus infection were observed in trees within 33 aspen clones, both deteriorating and nondeteriorating, in Utah. A virus was mechanically transmitted from five deteriorating clones to cowpea (Vigna unguiculata). Sucrose density-gradient centrifugation of one isolate of the virus revealed a single infectious component with a sedimentation velocity of $S_{20, w}=110$. Electron micrographs of the purified virus showed isometric particles $28 \pm 1 \mathrm{~nm}$ diameter. Properties of the purified aspen virus and its antiserum showed the virus to be an isolate of tobacco necrosis virus (TNV-A). This is the first report of TNV in aspen. Two additional isolates of TNV antigenically dissimilar to TNV-A and to each other were recovered from one of the same five deteriorating clones. Healthy rooted aspen suckers were infected with purified TNV-A by mechanical inoculation. The possible role of virus infection in aspen deterioration is discussed. ForEST SCI. 25:557-567.
\end{abstract}

Additional Key words. Populus tremuloides, tree virus dieback.

AsPen DETERIORATION is characterized by clones of quaking aspen (Populus tremuloides Michx.) having low vigor, poor form, increased mortality, and scarcity of regeneration by root suckers. It is widespread throughout the middle Rocky Mountain regions of Utah, Colorado, southern Idaho, and Wyoming (Schier 1975). Berbee and others (1976) describe a similar decline of unknown origin within a collection of poplar species and clones in Wisconsin. Site conditions, age, genotype, insects and disease, browsing by ungulate mammals, and an apical dominance mechanism preventing regeneration by root suckers have been reported as contributing causal factors (Schier 1975, Gruell and Loope 1974, Smith and others 1972, Wall 1971, Schier and Campbell 1976, Krebill 1972). The exact etiology of aspen deterioration, however, remains unknown.

Aspen spreads by root suckers (Fig. 1C). Adventitious shoots arising from expanding root systems produce groups of genetically identical individuals: natural clones. Virus infections are persistent and widespread in other vegetatively propagated trees, notably fruit trees. This suggested to us an investigation of possible virus involvement in deteriorating aspen.

Viruses have been far more difficult to recover from forest trees than from

The authors are, respectively, Plant Pathologist, Kitchawan Research Station of the Brooklyn Botanic Garden, Ossining, New York 10562; Professor, Life Science Department, Indiana State University, Terre Haute, Indiana 47809; and Research Assistant, Kitchawan Research Station. This work was supported by cooperative grants from the Intermountain Range and Forest Experiment Station, USDA Forest Service, Logan, Utah. The authors acknowledge the guidance and cooperation of Drs. George A. Schier and Richard G. Krebill, USDA Forest Service. Manuscript received 24 August 1978. 
herbaceous plants (Fulton 1966). Consequently, our approach was first to determine whether or not viruses could be found in deteriorating aspen. If so, the second step would be to survey both healthy and deteriorating clones for the identified viruses.

This paper reports the isolation and identification of tobacco necrosis virus from deteriorating aspen clones in Utah. A preliminary report has been published (Hibben and others 1977).

\section{Materials and Methods}

Inspection of Aspen Clones and Collection of Samples.-Forty-two healthy and deteriorating aspen clones were examined for foliar symptoms indicative of virus infection (SVI), especially chlorotic spots, line patterns, and abnormalities in size, color, and shape. Leaves for virus recovery attempts were collected only from trees with SVI. Catkins, buds, and root segments $12-18 \times 1-2 \mathrm{~cm}$ were also collected from a few trees with SVI. All samples were placed immediately in a cooled insulated container until transfer to storage at $4^{\circ} \mathrm{C}$.

The locations and sampling dates were: Logan Canyon, in the Wasatch National Forest in northern Utah, June 15-21, August 14-15, 1975, and August 30, September 3-4, 1976; Bridger National Forest (Salt Water Canyon and headwaters of the Salt River) in southwestern Wyoming, August 31, 1976; and MantiLasal National Forest (Ephraim Canyon) in central Utah, September 1, 1976. Additional leaf and root samples were collected June 11, 1976 by R. N. Campbell (Intermountain Range and Forest Experiment Station, USDA Forest Service, Logan, Utah) and sent to Kitchawan.

Virus Transmission from Aspen to Herbaceous Plants.-Aspen leaves were rinsed in running tapwater and pulped with an additive in a Sorvall Omni-Mixer (Norwalk, Conn. 06852). Several additives were tried, including sodium thioglycollate plus sodium diethyldithiocarbamate in phosphate buffer (Hibben 1966), nicotine sulfate in phosphate buffer (Kirkpatrick and Lindner 1964), polyethylene glycol (Hsu and Black 1973), and 3-5 percent polyvinylpyrrolidone in $0.05 \mathrm{M}$ phosphate buffer, $\mathrm{pH} 7$ (PVP). Mechanical inoculations of carborundum-dusted virus indicator plants were made with both crude and concentrated extracts. The latter were prepared by differential centrifugation of crude extracts, with clarification at $10,000 \mathrm{rpm}$ for $10 \mathrm{~min}$ and sedimentation at $30,000 \mathrm{rpm}$ for $3 \mathrm{~h}$ in a \#30 rotor (L3-40 ultracentrifuge, Beckman Instruments, Irvine, Ca. 92664). The high speed pellets were resuspended in $2 \mathrm{ml}$ of $0.05 \mathrm{M}$ phosphate buffer, $\mathrm{pH} 7$. Aspen catkins were treated as the leaves.

Plants inoculated with aspen leaf extracts were: cowpea (Vigna unguiculata (L.) Walp. cvs 'Black-eye' and 'California No. 5'), bean (Phaseolus vulgaris L. cvs 'Bountiful' and 'Pinto'), tobacco (Nicotiana tabacum L. 'NN'), cucumber (Cucumis sativus L. cv 'Marketmore'), Chenopodium amaranticolor Coste and Reyn., squash (Cucurbita maxima Duchesne cv 'Table Queen'), globe amaranth (Gomphrena globosa L.), and Datura stramonium L. All plants were grown from seed in vermiculite in styrofoam cups. For the cowpea, bean, cucumber, and squash, 6-10 plants were inoculated for each assay; for the rest, 1-3 plants per assay. Control plants were rubbed with buffer only. Inoculated plants were held 2-3 weeks in the greenhouse for symptom expression.

For the aspen bud assay, $25 \mathrm{~g}$ of unopened buds from trees with SVI in five deteriorating clones in the Logan Canyon and Manti-Lasal locations were combined into a composite sample. It was extracted with 3 percent PVP as described for leaves.

Aspen root pieces were washed, dusted with captan fungicide, inserted in a vermiculite-perlite $(1: 1) \mathrm{mix}$ in trays, and kept moist to force suckers. Composite

\section{8 / Forest SCIENCE}


samples of young suckers (leaves and stems) were treated as described for aspen leaves.

Host Range.-The aspen virus isolate was mechanically inoculated to the indicator plants listed above. Plants not showing symptoms were confirmed as noninfected by assaying crude juice from their leaves on cowpea.

Properties in Crude Juice.-Aging in vitro, thermal inactivation, and dilution end point tests were conducted with undiluted crude juice from infected cowpeas according to standard methods (Ross 1964).

Virus Clarification and Purification.-One aspen virus isolate was propagated in cowpea primary leaves. Several clarification methods with cowpea extracts were tried, including blending with chloroform (Bozarth and Chow 1966), chloroform and butanol (Steere 1956), and polyethylene glycol (Hsu and Black 1973). Buffers ranging in ionic strength from 0.01 to $0.2 \mathrm{M}$ and $\mathrm{pH}$ from 5 to 8 were tested. Results were evaluated by centrifugation on $10-40$ percent sucrose density gradients for $2 \mathrm{~h}$ at 39,000 rpm and analyzing the gradients with an ISCO (Lincoln, $\mathrm{Nb}$. 68505) model 640 density-gradient fractionator and ISCO UA-5 monitor as previously described (Hibben and Bozarth 1972). The following method produced the cleanest preparation. Infected cowpea leaves (100-200 g) were triturated in $0.01 \mathrm{M}$ acetate buffer, $\mathrm{pH} 5$, in a food blender. The extracts were filtered through cheesecloth, concentrated by differential centrifugation and centrifuged on sucrose density gradients in a Beckman Ti-15 zonal rotor as described by Bozarth (1977). The virus band was collected and pelleted from the sucrose solutions by centrifuging $12-15 \mathrm{~h}$ at $30,000 \mathrm{rpm}$ in a Beckman \#30 rotor. The final pellets were resuspended in $0.01 \mathrm{M}$ potassium phosphate buffer, $\mathrm{pH} 7$.

Physicochemical Properties.-Sedimentation velocity and density in cesium chloride $(\mathrm{CsCl})$ were determined in a Beckman analytical ultracentrifuge equipped with scanner optics and electronic speed control. For sedimentation velocity the purified virus suspension was dialyzed against three changes of $0.01 \mathrm{M}$ phosphate buffer over $48 \mathrm{~h}$. Virus was analyzed at a concentration of about $0.6 \mathrm{OD}_{265 \mathrm{~nm}}$ per $\mathrm{ml}$. Viscosity and density of the dialyzate were determined as previously described (Bozarth 1977). Density in $\mathrm{CsCl}$ was determined as described for $\mathrm{Cs}_{2} \mathrm{SO}_{4}$ (Bozarth 1976).

Ultraviolet absorption spectra were determined in a Beckman 25 recording spectrophotometer. Electron micrographs of purified virus were done with a Zeiss EM9-2S electron microscope using carbon-coated Formvar grids negatively stained with 1 percent uranyl acetate (Hibben and Bozarth 1972).

Serology.-Antiserum to purified virus was prepared by intravenous injections of $2 \mathrm{mg}$ of virus suspension followed by 2 intramuscular injections of $2 \mathrm{mg}$ virus emulsified with Freunds Complete Adjuvant (Bacto, Ann Arbor, MI 48232) at 4-day intervals. The rabbit was bled 2 weeks after the last injection. Double diffusion serological tests (Ball 1974) were made on microslides using Gelman (Scientific Products, Obetz, OH 43207) equipment. Each set of 3 slides was coated with 1 percent agarose containing 0.85 percent $\mathrm{NaCl}$ plus 0.1 percent sodium azide. Ten $\mu \mathrm{l}$ aliquots of antiserum and purified virus were placed in respective wells and incubated at $25^{\circ} \mathrm{C}$ for $24-48 \mathrm{~h}$ before determining precipitin reactions.

Mechanical Inoculation of Healthy Aspen.-Root segments 12-18 $\times 1-2 \mathrm{~cm}$ were collected from nondeteriorating aspen with no SVI. Root suckers were forced as described above. Cuttings from the suckers were rooted and grown in a soilless mix in pots. They were determined to be free of TNV by inoculating cowpeas with crude juice from 2-4 leaf samples per tree. The remaining tree leaves were then mechanically inoculated with purified virus adjusted to 15-20

Volume 25, Number 4, 1979 / 559 
$\mathrm{OD}_{260 \mathrm{~nm}} / \mathrm{ml}$. Two control trees were rubbed with buffer only. Twelve weeks after inoculation, virus recovery was attempted by grinding all leaves of each tree in 5 percent $\mathrm{PVP}, \mathrm{pH} 7$, and centrifuging the extract as previously described. Cowpeas were inoculated with the high speed pellet resuspended in phosphate buffer.

\section{RESULTS}

Symptoms in Aspen Clones.-Trees with foliar SVI were found in 9 of 10 and 19 of 21 deteriorating and nondeteriorating clones, respectively, in the Logan Canyon location. In June, symptoms consisted of faint chlorotic spots (Fig. 1D) plus mottle and chlorosis along veinlets. These symptoms progressed to light green, chlorotic, or reddish brown line patterns by August (Fig. 1E). When leaves turned yellow in September, the line patterns retained an orange pigmentation mixed with flecks of bifacial brown necrosis.

In the Ephraim Canyon location, 5 of 6 deteriorating clones examined had trees with chlorotic spots and mottle. Trees with SVI were not seen in the Bridger location, but a severe infestation by leaf miners may have masked symptoms.

In each clone with SVI, only a few scattered trees (up to an estimated 5 percent) showed symptoms. The SVI were confined to mature leaves; none appeared on young suckers.

Virus Transmission from Aspen to Herbaceous Plants.-Virus transmission was attempted from each of the 33 clones with trees showing SVI. An infectious agent was transmitted from five deteriorating aspen clones to cowpea. Four isolates were from the Logan Canyon location ( 2 from field trees and 2 from root suckers forced in the greenhouse), and one was from the Ephraim Canyon site. A sixth isolate was recovered from the composite bud extract. No infectious agent was recovered from aspen catkins.

The six aspen isolates were identified as viruses by serial transmission in cowpeas and by infectivity after passage through a $0.22 \mu \mathrm{m}$ membrane filter. They produced similar symptoms in cowpea and were tentatively assumed to be the same virus. One isolate (from deteriorating clone No. 6 in Logan Canyon) was chosen for identification.

Host Range.-Symptoms in cowpea consisted of reddish brown local lesions on inoculated primary leaves. If the lesions occurred near a vein, limited veinal necrosis occurred. No systemic symptoms developed. In bean, tobacco, $C$. amaranticolor, $C$. quinoa, and globe amaranth chlorotic and necrotic local lesions were produced without systemic infection.

From the host range and symptoms, we tentatively identified the aspen virus as an isolate of tobacco necrosis virus (TNV-A).

Properties in Crude Juice.-TNV-A was propagated in cowpea primary leaves for all identification work. When inoculated cowpeas were held in a growth chamber at $27-30^{\circ} \mathrm{C}$ for 16 -h days at $10.76 \mathrm{Klux}$ and $20-23^{\circ} \mathrm{C}$ nights, local lesions appeared within $48 \mathrm{~h}$, and maximum virus titer was reached in 3-4 days. The infectivity titer then declined as the heavily infected leaves (200-400 lesions per leaf) became completely necrotic.

The infectivity of crude juice extracts held at $25^{\circ} \mathrm{C}$ decreased by 97 percent after $24 \mathrm{~h}$ and was nil by $96 \mathrm{~h}$. The virus was inactivated by $65-70^{\circ} \mathrm{C}$ for $10 \mathrm{~min}$.

The dilution end point of TNV-A varied from $10^{-6}$ to $10^{-11}$. The higher values were obtained when inocula came from cowpeas at the highest virus titer, e.g., leaves collected 3-4 days after inoculation and just before severe necrosis. Additional dilution tests with purified TNV-A confirmed its high specific activity. Purified virus diluted to $2 \times 10^{-11} \mathrm{mg} / \mathrm{ml}$ produced an average of 4 lesions per inoculated leaf.

\section{0 / Forest SCIENCE}




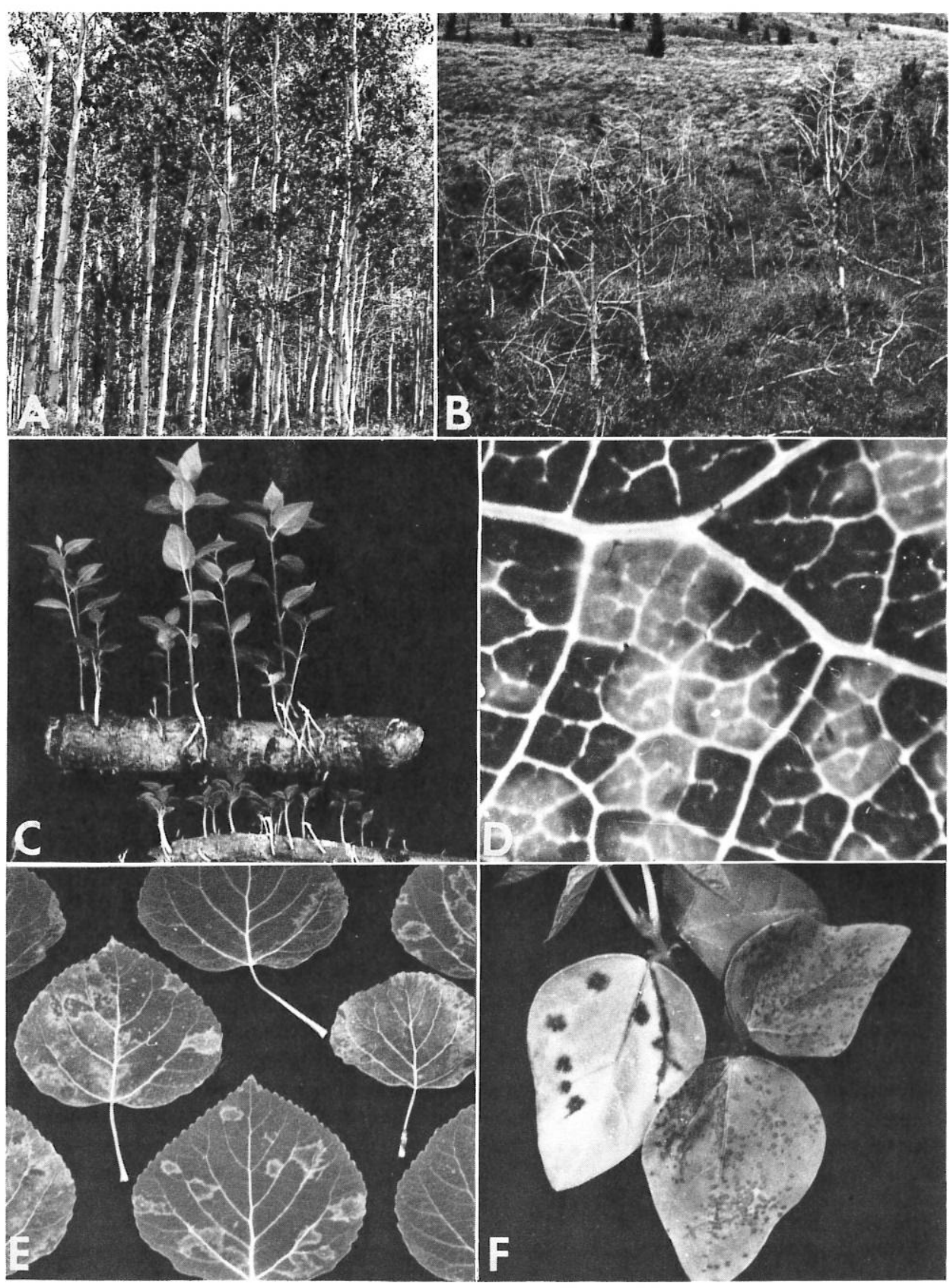

FIGURE 1. Nondeteriorating (A) and deteriorating (B) aspen clones in Wasatch National Forest, Logan Canyon, Utah. (C) Segments of aspen roots showing root suckers. (D and E) Symptoms on aspen leaves from Logan Canyon: (D) Chlorosis along small veins and chlorotic spots on leaf taken in June. (E) Chlorotic line patterns and mottle on leaves taken in August. (F) Symptoms caused by aspen isolate of TNV in primary leaves of cowpea.

Physicochemical Properties.-The ultraviolet absorbancy profile of sucrose density-gradient columns showed a single band (Fig. 2) with which infectivity was closely associated when fractions were assayed on cowpeas. The ultraviolet absorbancy spectrum of a fraction from this band had a $280: 260 \mathrm{~nm}$ ratio of 0.58 . 


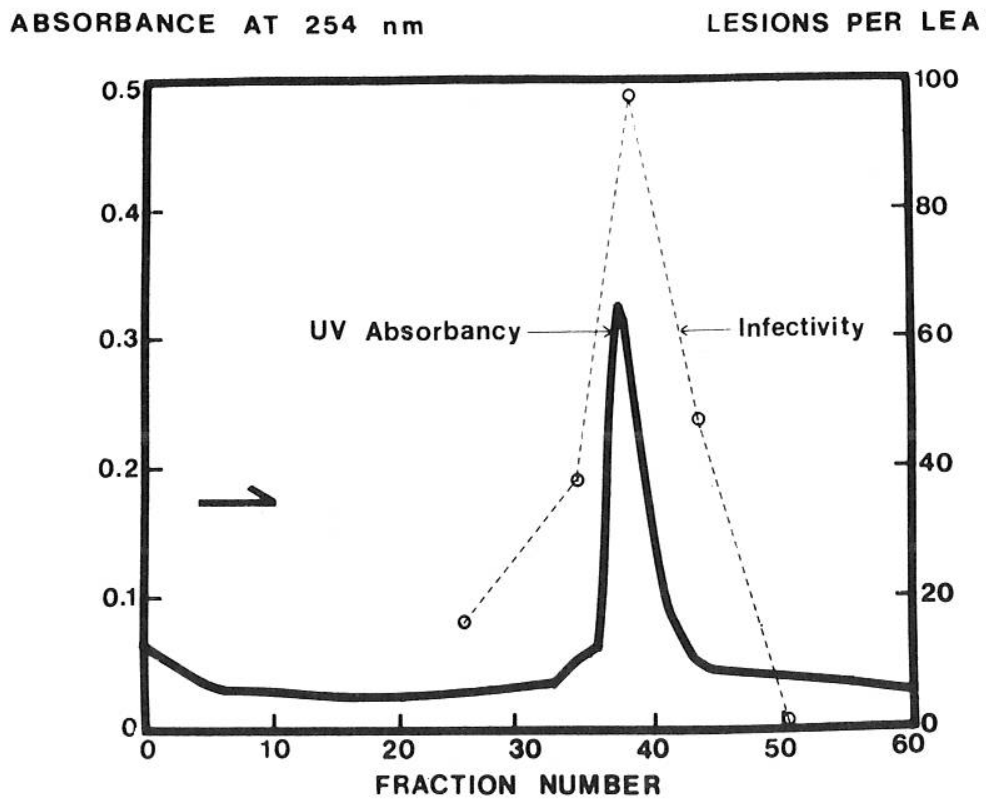

FIgURE 2. Optical density profile and infectivity following sucrose density-gradient centrifugation of the aspen isolate of TNV.

The band contained isometric particles of $28 \pm 1 \mathrm{~nm}$ diameter (Fig. 3). The virus sedimented at $\mathrm{S}_{20, \mathrm{w}}=110$ in the analytical ultracentrifuge and banded in $\mathrm{CsCl}$ at a density of $1.36 \mathrm{~g} / \mathrm{cm}^{3}$. No evidence of a satellite tobacco necrosis virus (Uyemoto and others 1968) was found.

Serology.-Antiserum to TNV-A had a homologous antiserum titer of 1:64 and did not react with normal serum or concentrated healthy cowpea sap. It reacted with a chrysanthemum $(\mathrm{Ch})$ isolate of TNV provided by J. K. Uyemoto (Kansas State Univ., Manhattan, KS 66506), a TNV isolate identified as AC-36 (from Uyemoto) and with 2 strains of TNV (ATCC-61, -68) from the American Type Culture Collection (Rockville, MD 20852) (Fig. 4). The aspen virus reacted with antisera to the Ch and tulip (Tp) (ATCC-PVAS-72) strains of TNV (Fig. 4), but not with antisera to the following viruses: pea enation mosaic, tobacco ringspot,

TABLE 1. Precipitin reactions of the aspen virus (TNV-A) when in adjacent wells with tobacco necrosis virus (TNV) antigens and tested against three TNV antisera by an agar double-diffusion method.

\begin{tabular}{clcl}
\hline \multirow{2}{*}{$\begin{array}{c}\text { TNV-A and the TNV } \\
\text { antigens } \\
\text { adjacent below in }\end{array}$} & \multicolumn{3}{c}{ TNV antisera ${ }^{\mathrm{a}}$ in center well } \\
\cline { 2 - 4 } adjel & TNV-A & Chrysanthemum & Tulip \\
\hline Maryland & no reaction & spurs & spurs \\
AC-36 & merging & merging & merging \\
Apple & no reaction & spurs & spurs \\
ATCC-61 & spurs & spurs & spurs \\
ATCC-68 & spurs & spurs & spurs \\
Chrysanthemum & merging & merging & merging \\
\hline
\end{tabular}

a Sources identified in text.

562 / Forest SCIENCE 


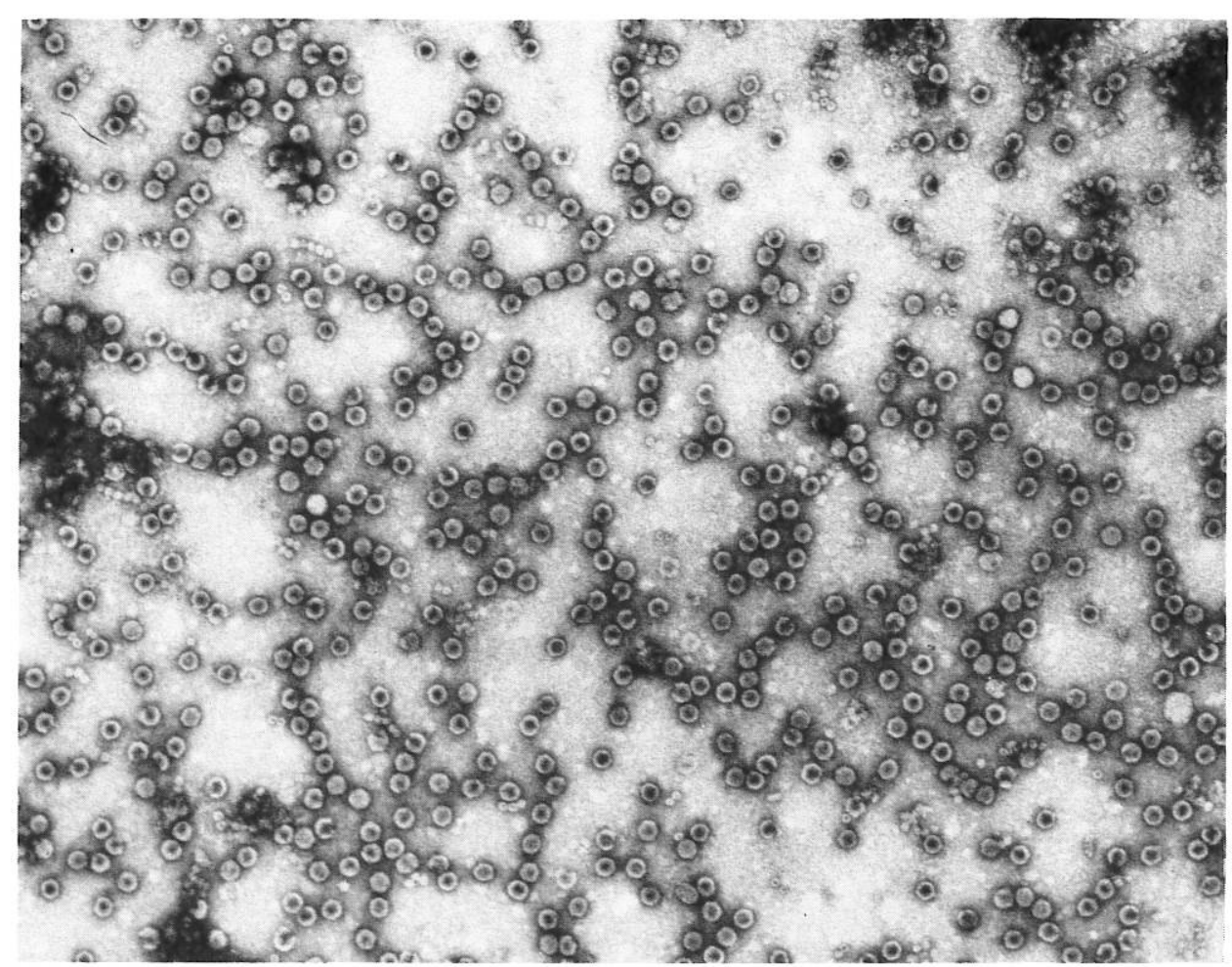

FIgURE 3. Electron micrograph of the aspen isolate of TNV. Particles $28 \pm 1 \mathrm{~nm}$ diameter.

tomato ringspot, cowpea mosaic, cowpea yellow mosaic, soybean mosaic, cucumber mosaic, carnation mottle, and tomato bushy stunt.

The serological tests confirmed the identity of the aspen virus as an isolate of TNV. To test the antigenic similarity of TNV-A with other isolates of TNV, the TNV-A antigen and each of the following TNV antigens were placed in alternate outer wells: a Maryland isolate provided by H. Waterworth (USDA, Beltsville, MD 20769), an apple isolate provided by J. Uyemoto, and the Ch, ATCC-61, ATCC-68, and AC-36 strains. The antigens were tested against the TNV-A, Ch, and Tp antisera, each placed in the center well. The results (Table 1 and Fig. 4) showed antigenic similarity only between TNV-A and the AC-36 and Ch isolates of TNV. Reciprocal tests with antiserum to strain AC-36 were not conducted because this antiserum was unavailable.

The remaining five virus isolates from deteriorating aspen clones were tested with TNV-A in the serological tests described. All six viruses were confirmed as antigenically similar isolates of TNV.

Attempts were made to re-isolate TNV-A from freeze-dried aspen leaves collected from deteriorating aspen clone No. 6 (Logan Canyon). The PVP and differential centrifugation method was used. Two additional isolates of TNV were recovered, but they were dissimilar antigenically from TNV-A and from each other. No attempt was made to purify these isolates, but their isolation indicates the presence of at least 3 serotypes (Babos and Kassanis 1963) of TNV in aspen.

Mechanical Inoculation of Aspen.-A virus was recovered from 7 of 10 inoculated trees and confirmed as TNV-A by serological methods. The inoculated leaves showed an occasional faint chlorotic lesion but no line patterns. No dieback occurred within the first year after inoculations. 
FIGURE 4. Serological precipitin reactions by the agar double-diffusion method. (A) Antiserum to the aspen isolate of TNV (a), its homologous antigen (c), Chrysanthemum TNV (b), normal serum (d). (B) Antiserum to the aspen isolate of TNV (a), its homologous antigen (b) and (d), AC-36 TNV (c). (C) Antiserum to the aspen isolate of TNV (a), its homologous antigen (b) and (d), ATCC-68 TNV (c). (D) Antiserum to the Chrysanthemum strain of TNV (a), Maryland TNV (b), aspen isolate of TNV (c), apple TNV (d).

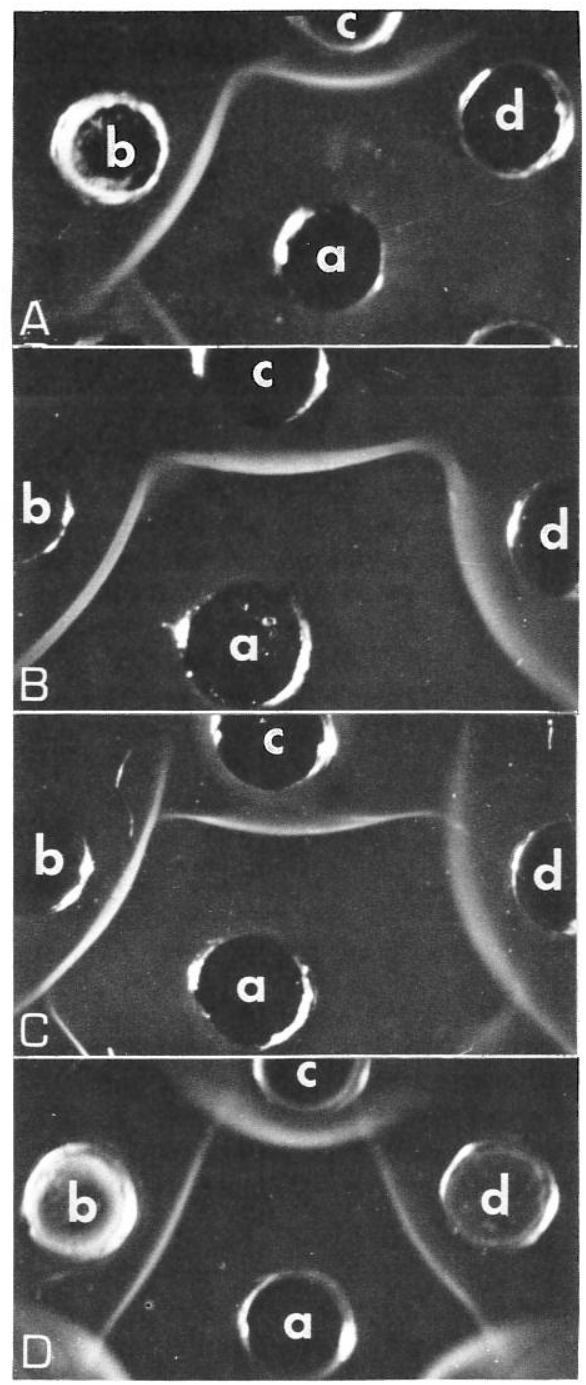

\section{Discussion}

A virus has been isolated from aspen and, from its biological, biophysical, and serological properties, identified as TNV. Two additional serotypes of TNV were recovered but not studied in detail.

Since TNV can be a greenhouse contaminant, our cowpea seed stock was thoroughly tested for a seed-borne TNV and none was found. No virus symptoms developed on control plants during assay work. Leaf-borne soil particles from the aspen sites could have been a source of TNV contamination, but all aspen leaves were rinsed in water before pulping. In repeated attempts to recover TNV from soil collected near aspens with SVI in Logan Canyon, no TNV was transmitted to cowpea. The separate isolations of TNV from five aspen clones, a composite bud sample, and repeatedly from a single clone make contamination unlikely as a source of the TNV isolates.

The physicochemical properties determined for TNV-A are within the accepted parameters for TNV. Estimates of sedimentation velocity of TNV range from

\section{4 / Forest SCIENCE}


$112 \mathrm{~S}$ to $130 \mathrm{~S}$ (Babos and Kassanis 1963). The $\mathrm{S}_{20, \mathrm{w}}=110$ for TNV-A is 6 percent below the value of $118 \mathrm{~S}$ accepted by Kassanis (1970) as the best estimate published before 1970. The ultraviolet absorbancy rates of $280: 260 \mathrm{~nm}=0.58$ and the buoyant density in $\mathrm{CsCl}$ of $1.36 \mathrm{~g} / \mathrm{cm}^{3}$ for TNV-A are compatible with the estimate of 19 percent nucleic acid for TNV (Kassanis 1970). The buoyant density of TNV-A is below the value of 1.399 reported for TNV by Cesati and Van Regenmortel (1969). The particle size of $28 \pm 1 \mathrm{~nm}$ for TNV-A falls within the range of 26-30 nm diameter reported for TNV (Kassanis 1970).

The dilution end point of TNV-A $\left(10^{-6}\right.$ to $\left.10^{-11}\right)$ was unexpectedly high; $10^{-6}$ has been reported for TNV (Kassanis 1970). The higher value, however, was achieved when the inoculum came from cowpea leaves at their maximum virus titer. Tests with purified virus also showed that TNV-A has a high specific activity. Kassanis and MacFarlane (1964) routinely transmitted TNV at a concentration of $10^{-8} \mathrm{mg} / \mathrm{ml}$.

The host range of TNV includes at least 88 species in 37 families of mostly herbaceous plants (Kassanis 1970). Although TNV has been identified in fruit trees (see below), to our knowledge this is the first report of TNV infection of a forest tree. Castello and Berbee (1978) have recently reported TNV in hybrid poplar clones. Other viruses infecting Populus species have been reported. Poplar mosaic virus, a flexous rod, infects several poplar clones and species in Great Britain and Europe (Biddle and Tinsley 1971) and in Canada (Navratil and Boyer 1970). Boyer (1962) discussed a leaf-spotting disease of possible virus origin in native and hybrid aspen in Canada. Berbee and others (1976) discovered a new poplar virus, a flexuous rod of the potato Y group, in five different Aigeiros clones in Wisconsin.

TNV is a soil-borne virus which is transmitted by zoospores of root-infecting chytrid fungi in the genus Olpidium (Teakle 1962). The virus often does not move systemically into the aboveground parts of herbaceous hosts (Price 1940). Our results indicate that TNV-A can infect the leaves of aspen. This agrees with previous reports of TNV in aboveground parts of grapevine (Cesati and Van Regenmortel 1969), citrus (Kassanis and Phillips 1970), pear (Kegler and others 1969), and apple (Uyemoto and Gilmer 1972).

Although TNV has been isolated from deteriorating aspen clones, there is insufficient evidence to implicate virus as a cause of deterioration. The rate of recovery was low (15 percent of clones having trees with SVI), but the difficulty of mechanically transmitting viruses from trees is recognized (Fulton 1966). Knowledge of the severity and range of TNV in aspen will depend on better methods for detecting viruses at low titer in woody hosts. The new technique of virus detection by enzyme-linked immunosorbent assay (EIA) (Voller and others 1976) offers a valuable means of surveying trees for known viruses. Our preliminary results indicate that TNV can be detected in dried aspen leaves by the EIA technique.

There are good reasons for further investigation of TNV and other viruses of aspen. The progressive decline of many vegetatively propagated crops has been attributed to infection by viruses (Hollings 1965). Virus infection of Populus species and hybrids when the trees are propagated by stem cuttings and grown in monoculture, as done in the north-central states (Berbee and others 1976), could result in significant yield reductions. If this virus, like other TNV strains, is vectored by root-infecting fungi, it might spread readily in a host like aspen, which propagates itself in nature by root sprouts.

\section{Literature Cited}

Babos, P., and B. Kassanis. 1963. Serological relationships and some properties of tobacco necrosis virus strains. J Gen Microbiol 32:135-144.

Volume 25, Number 4, 1979 / 565 
BALl, E. M. 1974. Serological tests for the identification of plant viruses. Am Phytopathol Soc, St. Paul, Minn. $31 \mathrm{p}$.

Berbee, J. G., J. O. Omuemu, R. R. Martin, and J. D. Castello. 1976. Detection and elimination of viruses in poplars. Intensive plantation culture, five years research. USDA Forest Serv Gen Tech Rep NC-21:85-91.

Biddle, P. G., and T. W. Tinsley. 1971. Poplar mosaic virus in Great Britain. New Phytol 70: 61-66.

Boyer, M. G. 1962. A leaf-spotting disease of hybrid and native aspen. Can J Bot 40:1237-1242.

BozarTH, R. F. 1976. The buoyant density of three double-stranded RNAs in cesium sulfate. Biochem et Biophys Acta 442:32-36.

BozARTH, R. F. 1977. Biophysical and biochemical characterization of virus-like particles containing a high molecular weight ds-RNA from Helminthosporium maydis. Virology 80:149-157.

Bozarth, R. F., and C. C. Chow. 1966. Pea enation mosaic virus: purification and properties. Contrib Boyce Thompson Inst 23:301-309.

Castello, J. D., and J. G. Berbee. 1978. The detection and elimination of viruses from hybrid poplar clones. Phytopath News 12:186.

Cesati, R., and M. H. Van Regenmortel. 1969. Serological detection of a strain of tobacco necrosis virus in grapevine leaves. Phytopathol Z 64:362-366.

Fulton, R. W. 1966. Mechanical transmission of viruses of woody plants. Annu Rev Phytopathol 4:79-102.

Gruell, G. E., and L. L. Loope. 1974. Relationships among aspen, fire, and ungulate browsing in Jackson Hole, Wyoming. USDA Forest Serv and USDI Park Serv, US Gov Print Office, Washington, D.C. 33 p.

Hibben, C. R. 1966. Transmission of a ringspot-like virus from leaves of white ash. Phytopathology 56:323-325.

Hibben, C. R., and R. F. Bozarth. 1972. Identification of an ash strain of tobacco ringspot virus. Phytopathology 62:1023-1029.

Hibben, C. R., J. Reese, and R. F. Bozarth. 1977. The identification of tobacco necrosis virus in deteriorating clones of aspen. Proc Am Phytopath Soc 4:83.

Hollings, M. 1965. Disease control through virus-free stock. Annu Rev Phytopath 3:367-396.

Hsu, H. T., and L. M. BLACK. 1973. Polyethylene glycol for purification of potato yellow dwarf virus. Phytopathology 63:692-696.

Kassanis, B. 1970. Tobacco necrosis virus. CMI/AAB Descriptions of plant viruses. No. 14, 4 p.

Kassanis, B., and I. MacFarlane. 1964. Transmission of tobacco necrosis virus by zoospores of Olpidium brassicae. J Gen Microbiol 36:79-93.

Kassanis, B., and M. P. Phillips. 1970. Serological relationship of strains of tobacco necrosis virus and their ability to activate strains of satellite virus. J Gen Virol 9:119-126.

Kegler, H., E. Proll, H. B. Schmidt, and H. Opel. 1969. Nachweis des tabaknekrosevirus (tobacco necrosis virus) in obstgeholzen. Phytopathol Z 65:21-42.

Kirkpatrick, H. C., and R. C. Lindner. 1964. A mechanically transmissible virus latent in apple. Phytopathology 54:229-232.

KrebiLL, R. G. 1972. Mortality of aspen on the Gros Ventre elk winter range. USDA Forest Serv Res Pap Int-129, 16 p.

Navratil, S., and M. G. Boyer. 1970. The identification of poplar mosaic virus in Canada. Can J Bot 46:722-723.

Price, W. C. 1940. Comparative host ranges of six plant viruses. Am J Bot 27:530-541.

Ross, A. F. 1964. Identification of plant viruses. In Plant virology (M. K. Corbett and H. D. Sisler, eds), p 68-92. Univ Florida Press, Gainesville. 527 p.

Schier, G. A. 1975. Deterioration of aspen clones in the middle Rocky Mountains. USDA Forest Serv Res Pap INT-170, $14 \mathrm{p}$.

Schier, G. A., and R. B. Campbell. 1976. Differences among Populus species in ability to form adventitious shoots and roots. Can J Forest Res 6:253-261.

Smith, A. D., P. A. Lucas, C. O. Baker, and G. W. Scotter. 1972. The effects of deer and domestic livestock on aspen regeneration in Utah. Utah Div Wildlife Res Pub 72-1, 32 p.

Steere, R. L. 1956. Purification and properties of tobacco ringspot virus. Phytopathology 46:60-69.

TEAKLE, D. S. 1962. Transmission of tobacco necrosis virus by a fungus, Olpidium brassicae. Virology 18:224-231.

Uyemoto, J. K., and R. M. Gilmer. 1972. Properties of tobacco necrosis virus strains isolated from apple. Phytopathology 62:478-481.

\section{6 / Forest Science}


Uyemoto, J. K., R. G. Grogan, and J. R. Wakeman. 1968. Selective activation of satellite virus strains by strains of tobacco necrosis virus. Virology 34:410-418.

Voller, A., A. Bartlett, D. E. Bidwell, M. F. Clark, and A. N. Adams. 1976. The detection of viruses by enzyme-linked immunosorbent assay (ELISA). J Gen Virol 33:165-167.

WALL, R. F. 1971. Variation in decay in aspen stands as affected by their clonal growth pattern. Can J Forest Res 1:141-146. 